\title{
Expression patterns of $\beta$ ig-h3 in chondrocyte differentiation during endochondral ossification
}

\author{
Min-Su Han ${ }^{1,2}$, Jung-Eun Kim ${ }^{1,3,5}$, \\ Hong-In Shin ${ }^{4}$ and In-San Kim ${ }^{1,2}$ \\ ${ }^{1}$ Cell and Matrix Research Institute \\ ${ }^{2}$ Department of Biochemistry and Cell Biology \\ ${ }^{3}$ Department of Molecular Medicine \\ Kyungpook National University School of Medicine \\ Daegu 700-422, Korea \\ ${ }^{4}$ Department of Oral Pathology \\ Institute for Hard tissue and Bio-tooth Regeneration \\ Kyungpook National University School of Dentistry \\ Daegu 700-422, Korea \\ ${ }^{5}$ Corresponding author: Tel, 82-53-420-4949; \\ Fax, 82-53-426-4944; E-mail, kjeun@knu.ac.kr \\ DOI 10.3858/emm.2008.40.4.453
}

Accepted 30 April 2008

Abbreviations: Col $\mathrm{X}$, type $\mathrm{X}$ collagen; $\mathrm{PC}$, perichondrium; $\mathrm{PH}$, prehypertrophic chondrocytes; PO, periosteum; $\beta$ ig-h3, TGF- $\beta$ induced gene

\begin{abstract}
$\beta$ ig-h3 is a TGF- $\beta$-induced extracellular matrix protein which is expressed in many tissues including bones and cartilages. In previous reports, we showed that ßig-h3 mediates cell adhesion and migration and, especially in bones, negatively regulates the mineralization in the end stage of endochondral ossification. Here, to elucidate the expression pattern and role of $\beta$ ig-h3 in chondrocyte differentiation, ATDC5 chondrocytes and embryonic and postnatal mice were used for in vitro differentiation studies and in vivo studies, respectively. $\beta$ ig-h3 was strongly induced by the treatment of TGF- $\beta 1$ and the expression level of $\beta i g-h 3$ mRNA and protein were highly expressed in the early stages of differentiation but decreased in the late stages in ATDC5. Furthermore, the patterns of TGF- $\beta 1$, $-\beta 2$, and $-\beta 3$ mRNA expression were concurrent with $\beta i g-h 3$ in ATDC5. $\beta i g-h 3$ was deeply stained in perichondrium (PC), periosteum (PO), and prehypertrophic chondrocytes $(\mathrm{PH})$ through the entire period of endochondral ossification in mice. $\beta$ ig-h3 was mainly expressed in $\mathrm{PC}$ and $\mathrm{PH}$ at embryonic days and obviously in $\mathrm{PH}$ in postnatal days. These results suggest that $\beta i g-h 3$ may play a critical role as a regulator of chondrogenic differentiation in endochondral ossification.
\end{abstract}

Keywords: cell differentiation; chondrocytes; osteogenesis; transforming growth factor- $\beta$

\section{Introduction}

Bone formation in vertebrates is classified into intramembranous and endochondral ossification (Olsen et al., 2000). The flat bones, which are found in the skull and mandible, are formed by intramembranous ossification whereas most other bones are produced by endochondral ossification arising from a cartilaginous template. During the endochondral ossification process, mesenchymal cells differentiate into chondrocytes following that the chondrocytes differentiate into the proliferative, prehypertrophic, hypertrophic and, finally calcified chondrocytes. In vivo and in vitro differentiation of chondrocytes is primarily characterized by the expression of the extracellular matrix (ECM) proteins including collagens (Metsaranta et al., 1992; Nakata et al., 1993), proteoglycans (Goetinck, 1991), and non-collagenous glycoproteins (Chen et al., 1995). With many reports for ECM proteins regulating chondrocyte differentiation, it has been suggested that ECM proteins may be one of the most important controllers for endochondral ossification.

$\beta$ ig-h3 is an ECM protein that is first identified in a human lung adenocarcinoma cell line by treatment of TGF- $\beta 1$ (Skonier et al., 1992) and is strongly induced by TGF- $\beta$ in various types of cells (Skonier et al., 1994; LeBaron et al., 1995; Thapa et al., 2007). Big-h3 is ubiquitously detected in normal tissues such as the heart, kidneys, liver, and skin and involved in cell adhesion, growth and migration, tumorigenesis, wound healing, and apoptosis, indicating that it may have an important function throughout the body (Skonier et al., 1992; 1994; Kim et al., 2000a; 2002; 2003; Park et al., 2004; Lee et al., 2006; Jung et al., 2007). During mouse embryogenesis, $\beta$ ig-h3 is mainly expressed in bones, cartilages and other mesoderm-derived organs (Schorderet et al., 2000). Our recent study has demonstrated the involvement of Big-h3 in endochondral ossification showing the inhibitory effect and molecular mechanisms on osteoblast differentiation (Kim et al., 2000b; Thapa et al., 2005). Members of the TGF- $\beta$ superfamily are important regulators of chondrocyte differentiation during endochondral ossification. Several studies 
report that TGF- $\beta$ localizes in hypertrophic chondrocytes and vascular structure (Thorp et al., 1992), and TGF- $\beta$ mediated differentiation of hypertrophic chondrocytes is required for the maintenance of the articular cartilage (Yang et al., 2001) and is involved in apoptosis (Gibson et al., 2001). These reports imply that $\beta$ ig-h3 induced by TGF- $\beta$ may be involved in endochondral ossification. However, the precise expression pattern and function of $\beta$ ig-h3 in chondrocyte differentiation during endochondral ossification still remains obscure.

The present study was designed to investigate ßig-h3 expression patterns during endochondral ossification. $\beta$ ig-h3 was dramatically induced by TGF- $\beta 1$ in ATDC5, mouse embryonic carcinoma derived cell line which is frequently used for the in vitro model of chondrocyte differentiation (Akiyama et al., 1997). We analyzed the expression pattern of $\beta$ ig-h3 and chondrogenic marker genes during chondrocyte differentiation and examined the $\beta$ ig-h3 expression in long bones during mouse development. Thus, the importance of $\beta$ ig-h3 mediating chondrogenic differentiation was indicated.

\section{Materials and Methods}

\section{Cell culture}

The mouse embryonic carcinoma derived chondrocyte cell line, ATDC5 was cultured in a 1:1 mixture of DMEM and Ham's F-12 (DMEM/F12) medium (Invitrogen corp., Carlabad, CA) supplemented with $5 \%$ FBS (Invitrogen), $10 \mu \mathrm{g} / \mathrm{ml}$ human transferrin (Roche, Germany), and $30 \mathrm{nM}$ sodium selenite (Sigma, St. Louis, MO). To examine the expression level of $\beta$ ig-h3 induced by TGF- $\beta 1$ treatment, ATDC5 cells were plated at a density of $2 \times 10^{5}$ cells/well in 6-well culture dishes, grown to $80 \%$ confluency, and then treated for $48 \mathrm{~h}$ with various concentrations $(0,0.2$, and $1 \mathrm{ng} / \mathrm{ml})$ of recombinant TGF- $\beta 1$ (R\&D systems, Minneapolis, $\mathrm{MN}$ ). Cultured media were collected, lyophilized, and analyzed by western blotting. To investigate the $\beta$ ig-h3 expression during differentiation, ATDC5 cells were seeded in 6-well culture dishes at a density of $6 \times 10^{4}$ cells/well and cultured in media additionally supplemented with $10 \mu \mathrm{g} / \mathrm{ml}$ of human insulin (Lilly, Indianapolis, IN). After 21 days, the culture medium was switched to minimal essential medium-alpha ( $\alpha$-MEM, Invitrogen) and grown at $3 \% \mathrm{CO}_{2}$ to facilitate hypertrophy and mineralization of cells. On days $4,7,14,21,28,35$, and 42, culture media and cells were harvested for western and northern blot analysis.

\section{Western blot analysis}

The harvested culture media were lyophilized prior to western blotting. Three $\mu \mathrm{g}$ of each sample was mixed with a $2 \times$ sample buffer $(100 \mathrm{mM}$ Tris- $\mathrm{HCl}$, $\mathrm{pH} 6.8,200 \mathrm{mM}$ DTT, 4\% SDS, 0.2\% bromophenol blue, and $20 \%$ glycerol) and boiled for $5 \mathrm{~min}$. Then, the samples were subjected to $10 \%$ SDS-PAGE and transferred to a nitrocellulose membrane (Amersham, UK). The membrane was incubated for $2 \mathrm{~h}$ at room temperature (RT) with anti-mouse $\beta$ ig-h3 antiserum (diluted 1:2,000 in PBS) and reacted with peroxidase-conjugated anti-rabbit lgG antibody (diluted 1:2,000, Amersham). The blot was then identified by the enhanced chemiluminescence (ECL) system (Amersham).

\section{Total RNA isolation and northern blot analysis}

Total RNA was isolated from cultured ATDC5 cells using the TRIzol reagent (Invitrogen) according to the manufacturer's instructions. Ten $\mu \mathrm{g}$ of total RNA was fractionated on $1 \%$ agarose gel containing formaldehyde, transferred onto a nylon membrane (Amersham) by capillary method using $20 \times$ sodium chloride sodium citrate buffer (SSC, $\mathrm{pH}$ 7.0), and cross-linked to membranes by UV irradiation (UV Stratalinker 1800, Stratagene, La Jolla, CA). DNA probes were labeled with $30 \mu \mathrm{Ci}$ $\left[\alpha-{ }^{32} P\right]$ dCTP using a random priming Megaprime DNA labeling Kit (Amersham). The hybridization was performed at $68^{\circ} \mathrm{C}$ for $3 \mathrm{~h}$ using ExpressHyb hybridization solution (Clontech, Mountain View, CA). After hybridization, the membranes were sequentially washed with $2 \times$ SSC $/ 0.05 \%$ SDS and $0.1 \times$ SSC $/ 0.1 \%$ SDS solutions to remove nonspecific bound probes and then exposed to X-ray film (AGFA) for 3 days at $-70^{\circ} \mathrm{C}$ before development to detect hybridization signals.

\section{Immunohistochemistry}

To analyze the expression pattern of $\beta$ ig-h3, femora from ICR mice of embryonic day 13.5 (E13.5) and E15.5, and postnatal day 7 (P7) and P14 (Korea Biolink, Korea) were removed and fixed in $4 \%$ paraformaldehyde (PFA) in $0.1 \mathrm{M}$ sodium phosphate buffer for 16 to $42 \mathrm{~h}$ at $4{ }^{\circ} \mathrm{C}$. After fixation, the femora from postnatal mice were decalcified in $10 \%$ EDTA, pH 7.4 for 2 to 20 days. Then, specimens were dehydrated through ethanol series, embedded in paraffin, and cut into $5 \mu \mathrm{m}$ sections. Deparaffinized sections were quenched in $1 \%$ $\mathrm{H}_{2} \mathrm{O}_{2}$ in methanol, washed in PBS ( $\mathrm{pH} 7.8$ ), and blocked with normal goat serum for $2 \mathrm{~h}$ at RT. The 
sections were incubated overnight at $4^{\circ} \mathrm{C}$ with rabbit anti-mouse $\beta$ ig-h3 antiserum diluted 1:2000 in PBS. After washing in PBS, the sections were incubated with biotinylated-anti-rabbit IgG antibody for $1 \mathrm{~h}$ at RT, reacted for $1 \mathrm{~h}$ with VETASTAIN elite $A B C$ Reagent (Vector Laboratories, Burlingame, $\mathrm{CA}$ ) and then developed using DAKO Liquid DAB ${ }^{+}$ Substrate-Chromogen System (DAKO, Denmark). Counterstaining was performed with $1 \%$ methyl green in $\mathrm{dd}_{2} \mathrm{O}$. Non-immune rabbit IgG was used as a control of immunohistochemistry (IHC).

\section{In situ hybridization}

In situ hybridization on sections of mouse femora aged P7, P14, and P21 was performed by using [ $\left.{ }^{35} \mathrm{~S}\right]$ uridine triphosphate (UTP)-labeled riboprobes as described previously (Park et al., 2001). Antisense and sense riboprobes for $\beta$ igh3 digested with EcoRV or BamHI were produced by $\mathrm{T} 7$ and T3 RNA polymerase, respectively. A type $X$ collagen (ColX) probe was prepared as previously described (Inada et al., 1999). [ ${ }^{35}$ S] UTP-labeled riboprobes that adjusted to $5 \times 10^{4} \mathrm{cpm} / \mu \mathrm{l}$ were denatured and placed in each slide which was digested with $10 \mu \mathrm{g} / \mathrm{ml}$ proteinase $\mathrm{K}$. Hybridization was carried out overnight in a humidified box at

A

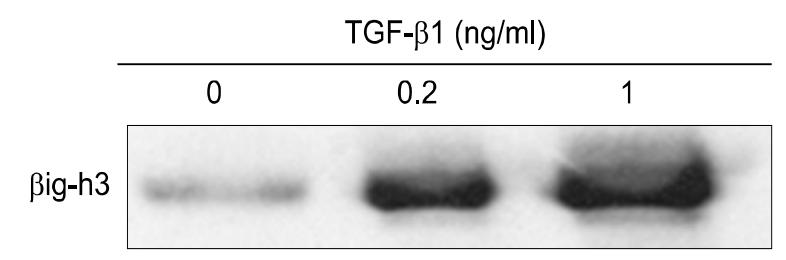

C

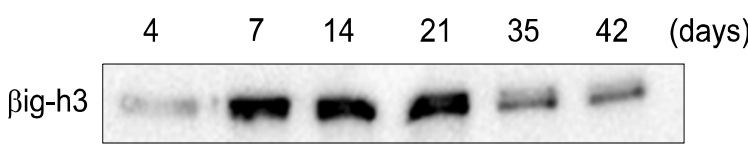

$52^{\circ} \mathrm{C}$, followed by high stringency washes with $50 \%$ formamide and $20 \mathrm{mM}$ DTT at $65^{\circ} \mathrm{C}$. For autoradiography, the dehydrated slides were dipped into photographic emulsion (Kodak NTB-2, Eastman Kodak, Rochester, NY), dried, and exposed for 2-3 weeks at $4^{\circ} \mathrm{C}$. The slides were then developed (Kodak D-19, Eastman Kodak), fixed (Kodak Unifix, Eastman Kodak), counterstained with hematoxylin, and mounted with DePeX (BDG). The tissue morphology and in situ hybridization result were examined under the bright field and dark field of the fluorescence microscope, respectively.

\section{Results}

\section{Expression of $\beta$ ig-h3 mRNA and protein during in vitro differentiation of ATDC5 cells}

As $\beta$ ig-h3 is known to be induced by TGF- $\beta$ in many different cells, we examined whether TGF- $\beta$ induces the expression of $\beta$ ig-h3 in ATDC5, a mouse embryonic carcinoma derived cell line. ATDC5 cells were treated with various concentrations of TGF- $\beta 1$ for $48 \mathrm{~h}$ and cultured media were then harvested to analyze the $\beta$ ig-h3 expression by western blotting (Figure 1A). Even

B

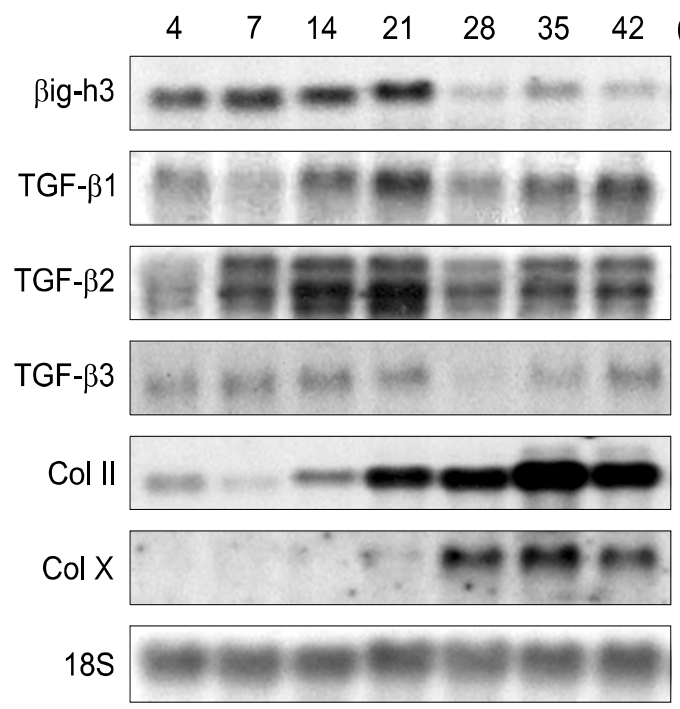

Figure 1. Expression of $\beta i g-h 3$ in differentiated ATDC5 cells. (A) TGF- $\beta 1$-induced $\beta$ ig-h3 expression in ATDC5 cells. The ATDC5 cells were seeded in 6 -well culture dishes at a density of $2 \times 10^{5}$ cells per well and treated with the indicated concentrations of TGF- $\beta 1$. After incubation for $48 \mathrm{~h}$, $\beta$ ig-h3 expression from culture media was analyzed by western blotting. (B) The mRNA expression of $\beta$ ig-h3 and marker genes during chondrogenic differentiation of ATDC5 cells. Total RNA was extracted from ATDC5 cells on indicated differentiation times and northern blotting was performed using specific probes for $\beta$ ig-h3, TGF- $\beta 1,-\beta 2$, $-\beta 3$, collagen type II (CollI), and X (CoIX). The consistency of RNA loading in each lane was evaluated by reprobing the membrane with 18S rRNA probe. (C) The expression of $\beta$ ig-h3 protein during chondrogenic differentiation of ATDC5 cells. ATDC5 cells were seeded at a density of $6 \times 10^{4}$ cells/well in 6-well dishes and differentiated for 42 days. On indicated time periods, cultured media were harvested and the expression levels of $\beta i g-h 3$ protein were determined by western blotting. 
though the endogenous $\beta$ ig-h3 level was quite low in ATDC5 cells, the expression of $\beta$ ig-h3 was induced by TGF- $\beta$ and the level of induced $\beta$ ig-h3 protein was prominent even at a low concentration of $0.2 \mathrm{ng} / \mathrm{ml}$ of TGF- $\beta 1$. To investigate the expression level of $\beta$ ig-h3 during chondrocyte differentiation, ATDC5 cells were differentiated into chondrocytes for 42 days under the insulin-induced culture condition. Time-dependent changes with cartilage nodule formation were verified in differentiated ATDC5 cells by alcian blue staining (data not shown). To determine the expression level of $\beta$ ig-h3 and marker genes during in vitro chondrogenic differentiation, northern blot analysis was performed at an indicated time point from differentiated
ATDC5 cells (Figure 1B). Up-regulation of $\beta$ ig-h3 expression was observed in an early time of in vitro differentiation and was sustained for 3 weeks prior to a rapid decrease at late stages of differentiation. Although the expression patterns of $\beta$ ig-h3 were similar to TGF- $\beta$ mRNA, unlike $\beta$ ig-h3, a weak expression of TGF- $\beta 1$ and $-\beta 2$ was still detected in the late stages of differentiation. Type $I$ and $X$ collagen, which are marker genes of chondrocyte differentiation, were also observed in differentiating ATDC5 cells. During in vitro differentiation, ATDC5 cells proliferated and formed cartilage nodules with an expression of type II collagen (CollI) and, subsequently, hypertrophied and synthesized type $X$ collagen (ColX) in the late stages of differen-
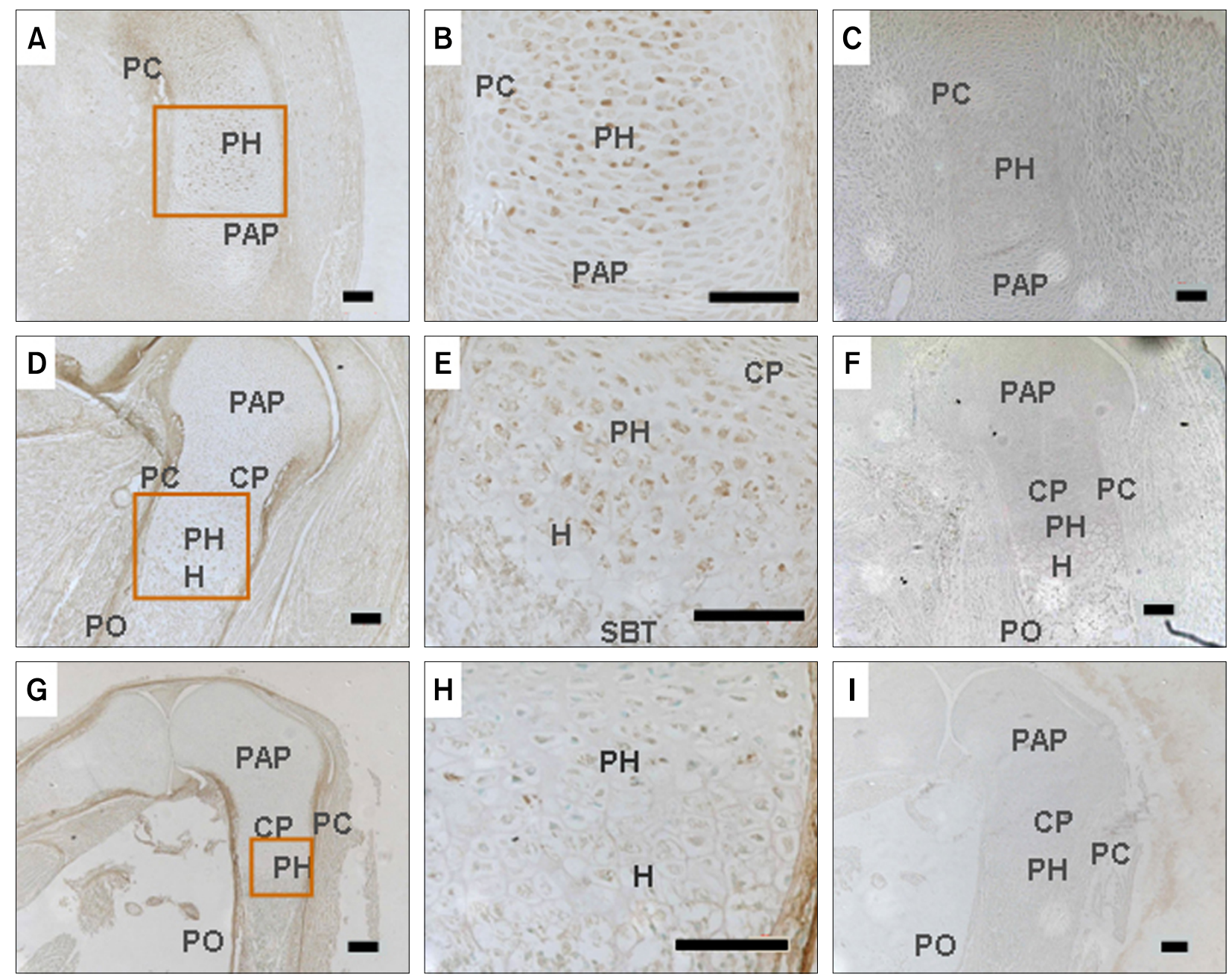

Figure 2. Immunohistochemical detection of $\beta$ ig-h3 protein in the femur of mouse embryos at embryonic periods. Paraffin sections from femoral bone of ICR mouse embryos at embryonic day 13.5 (E13.5) (A), E15.5 (D), and E18.5 (G) were prepared to detect Big-h3 protein with rabbit anti-mouse Big-h3 antibody as described in "Materials and Methods". The sections were treated with rabbit anti-mouse $\beta$ ig-h3 antibody (A, D, G) or non-immune rabbit lgG $(C, F, I) . B, E$, and $H$ were higher-magnification images corresponding to small rectangles of $A, D$, and $G$, respectively. CP, columnar proliferating chondrocytes; $\mathrm{H}$, hypertrophic chondrocytes; $\mathrm{PAP}$, periarticular proliferating chondrocytes; PC, perichondrium; $\mathrm{PH}$, prehypertrophic chondrocytes; $\mathrm{PO}$, periosteum; SBT, spongy bone trabeculae; Scale bar, $50 \mu \mathrm{m}(\mathrm{A}-\mathrm{C}) ; 100 \mu \mathrm{m}(\mathrm{D}-\mathrm{I})$. 
tiation (Figure 1B). Corresponding to mRNA expression, protein expression of $\beta$ ig-h3 was also highly increased at an early stage and maintained at a high level for 3 weeks of in vitro differentiation of ATDC5 cells. Then, its expression was dramatically decreased in subsequent days (Figure 1C). This finding indicates that the up-regulation of $\beta i g-h 3$ expression may be important for an early stage of chondrocyte differentiation.

\section{ßig-h3 protein expression in developing mouse femur}

To clarify the expression pattern of $\beta$ ig-h3 protein during endochondral ossification, an immunohistochemical study was performed in the mouse femur from embryonic $(E)$ to postnatal $(P)$ day. Periarticular proliferating chondrocytes (PAP) and prehypertrophic chondrocytes $(\mathrm{PH})$ were observed in cartilage condensation of the limb buds at E13.5 of mouse development. At this time, intensive expression of $\beta$ ig-h3 was observed in $\mathrm{PH}$ differentiated from the PAP and perichondrium (PC) (Figure 2, A and $\mathrm{B}$ ). Long bone at E15.5 of mouse has primary ossification center in which spongy bone trabeculae (SBT) and medullary cavity are observed. At E15.5, $\beta$ ig-h3 was widely expressed in many kinds of cells, intensively in the PH and PC, and weakly in periosteum (PO), which were shown in the femur of early embryonic development (Figure 2, D and $E)$. The expression of $\beta i g-h 3$ in the $P C$ and $P O$ was maintained in all subsequent stages of the endochondral ossification (Figure $2 \mathrm{G}$ and $\mathrm{H}$ ). No Big-h3 expression was observed in normal rabbit IgG as a negative control (Figure $2 \mathrm{C}, \mathrm{F}$, and I).

It was observed that $\beta$ ig-h3 expression was still retained in $\mathrm{PC}$ and $\mathrm{PO}$ of the long bones on day 7 after birth. (Figure 3A-C). Big-h3 was intensively expressed in the $\mathrm{PH}$ of the epiphysis in which secondary ossification center was observed. At $\mathrm{P} 14$, the strong expression of $\beta$ ig-h3 was continuously present in the $\mathrm{PH}, \mathrm{PC}$, and $\mathrm{PO}$ (Figure $3 \mathrm{E}-\mathrm{G})$. With the development of secondary ossification, $\beta$ ig-h3 was strongly expressed in the $\mathrm{PH}$ and newly formed spongy bone trabeculae (SBT) but weakly expressed in $\mathrm{H}$. The expression of Big-h3 was constantly observed for several weeks after birth. At 5 weeks of age, $\beta$ ig-h3 was still
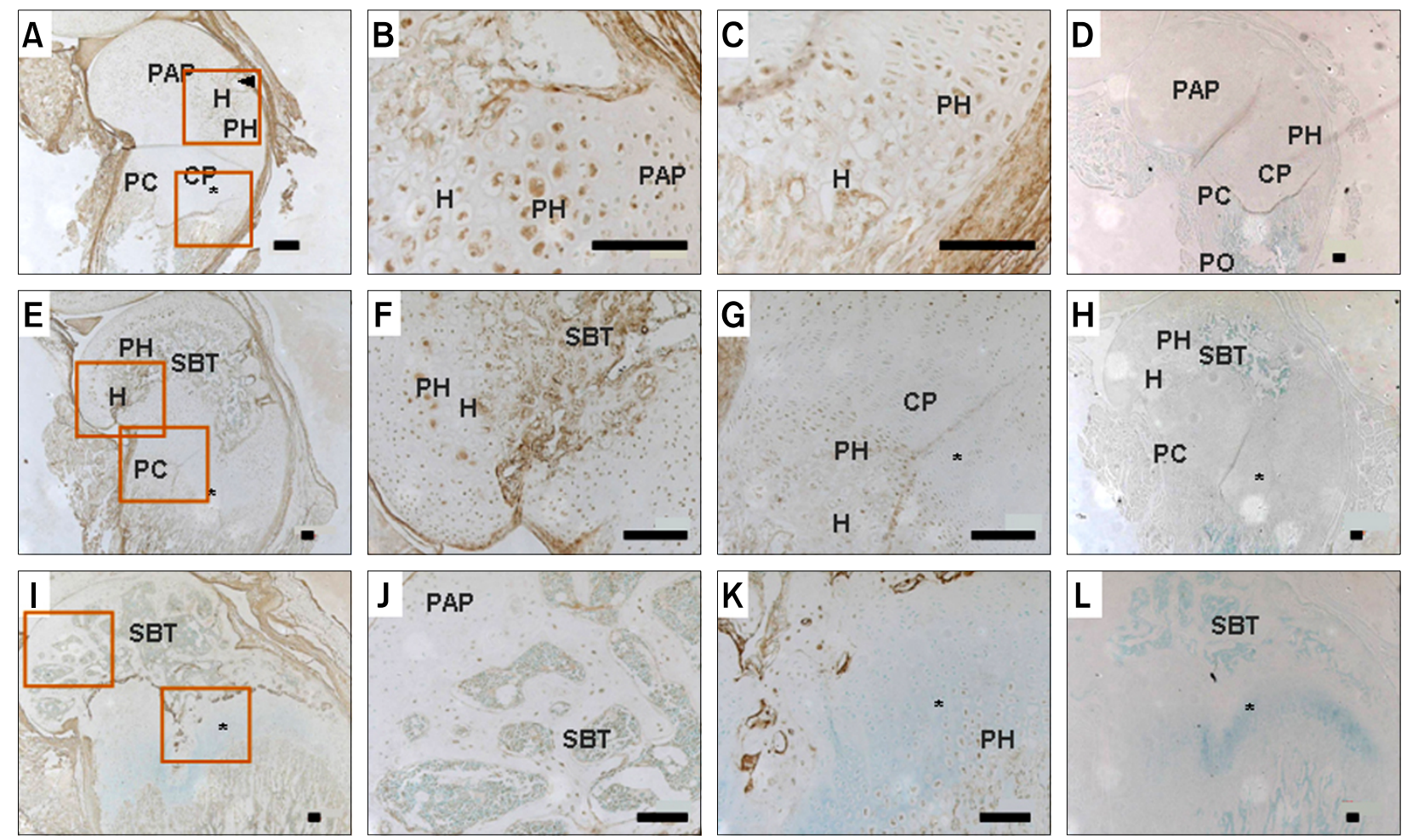

Figure 3. Immunohistochemical analysis of $\beta$ ig-h3 protein in mouse femur at postnatal periods. $\beta$ ig-h3 protein in mouse femoral bone at postnatal day 7 (P7) (A), P14 (E), and P35 (I) were detected with rabbit anti-mouse Big-h3 antibody as described in "Materials and Methods". The paraffin sections were treated with rabbit anti-mouse $\beta$ ig-h3 antibody $(A, E, I)$ or non-immune rabbit $\lg G(D, H, L)$. Images in column 2 and 3 were higher-magnification images corresponding to small rectangles in column 1. CP, columnar proliferating chondrocytes; $\mathrm{H}$, hypertrophic chondrocytes; PAP, periarticular proliferating chondrocytes; PC, perichondrium; PH, prehypertrophic chondrocytes; PO, periosteum; SBT, spongy bone trabeculae; arrowhead, starting point of secondary ossification center; asterisk, epiphyseal plate; Scale bar, $100 \mu \mathrm{m}$. 
expressed in the $\mathrm{PH}, \mathrm{PC}$, and $\mathrm{PO}$ including $\mathrm{ECM}$ surrounding chondrocytes (Figure $3, \mathrm{I}-\mathrm{K}$ ). Interestingly, the strong expression of Big-h3 was detected at the newly formed SBT of the secondary ossification center and in a region that was invaded by vascular structures containing osteoblasts, osteoclasts, and red marrow cells in the confines of epiphyseal plate. $\beta$ ig-h3 expression was not shown in normal rabbit IgG as a nonimmune control (Figure $3 \mathrm{D}, \mathrm{H}$, and L).

\section{Localization of $\beta \mathrm{ig}-\mathrm{h} 3$ and marker gene of chondrocyte differentiation in developing mouse femur}

To elucidate the expression of $\beta$ ig-h3 in chondrocytes during endochondral ossification, the localization of $\beta$ ig-h3 expression was compared to ColX, which is a marker for the hypertrophic zone. In situ hybridization was performed by using $\left[{ }^{35} \mathrm{~S}\right]$ UTPlabeled Big-h3 and ColX riboprobes on femoral sections of postnatal mice (Figure 4). Prominent expression of $\beta$ ig-h3 transcripts were detected in chondrogenic tissue destined for cartilage or bone formation. With the maturation of chondrocytes, a surge of $\beta i g-h 3$ expression occurred in the prehypertrophic and early hypertrophic chondrocytes, but not in the ColX positive hypertrophic zone. Sense probes did not show any significant signal with these tissues (data not shown).

\section{Discussion}

Endochondral bone ossification is an important process responsible for bone growth in the vertebrate skeleton, mainly in long bones during skeletal development. This is a complex process which requires the sequential formation and degradation of cartilaginous structures serving as templates for the developing bones. Precartilage condensation observed at the first stage of endochondral ossification is composed of undifferentiated mesenchymal stem cells (MSCs), which are multipotential to differentiate, and specific precartilage extracellular matrix molecules (ECMs), which regulate the differentiation of chondrocytes (Tacchetti et al., 1992; Hall and Miyake, 1995). Various ECMs in precartilage condensation have been understood to play important roles in the control of endochondral ossification.

ßig-h3, an ECM protein, is expressed in many tissues, including the heart, kidneys, liver, and cartilage (Skonier et al., 1992; LeBaron et al., 1995; Hashimoto et al., 1997). During the chick embryogenesis, $\beta$ ig-h3 was localized at the precartilage condensation of limb buds and highly expressed in the prehypertrophic in the vertebrae, indicating that this protein may have an important role in cartilage development (Ohno et al., 2002). During mouse development, ßig-h3 expression was high in pre-chondrocytic mesenchymal cells at
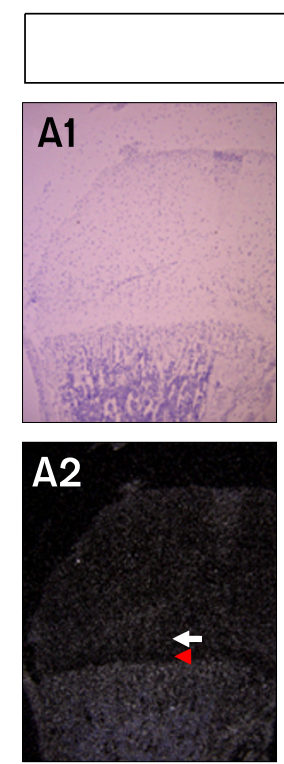

P7

\section{ßig-h3 mRNA}
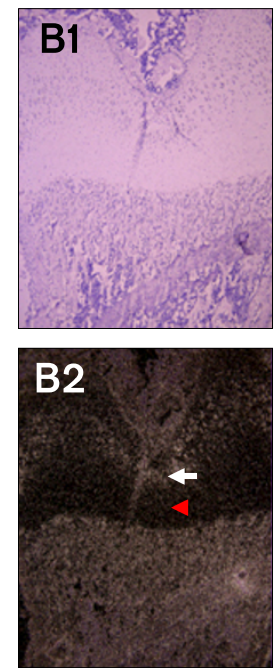

P14
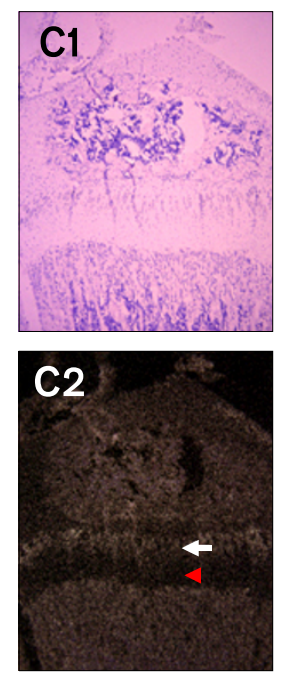

P21
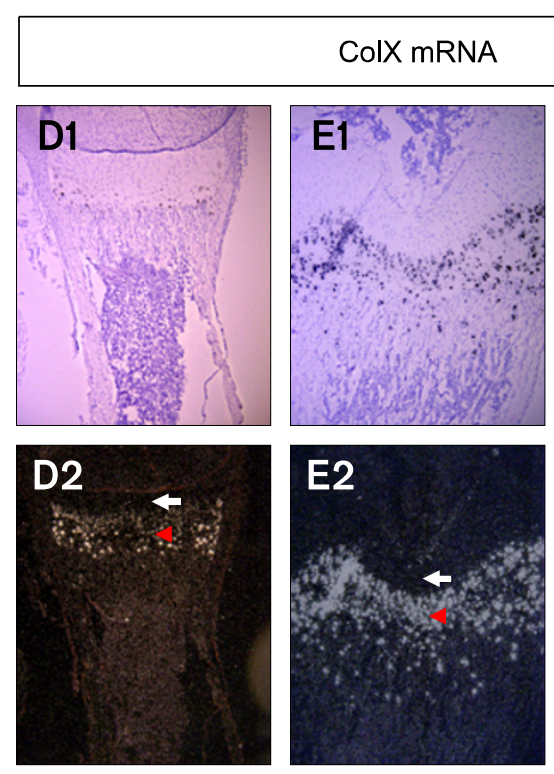

P14
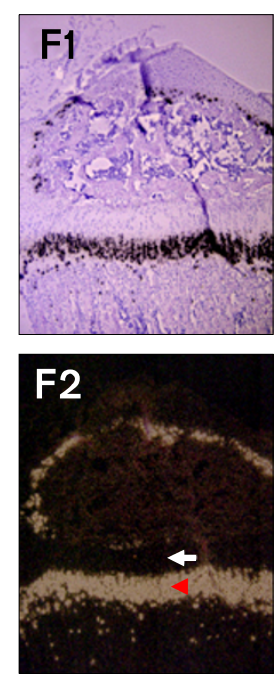

P21

Figure 4. In situ hybridization of $\beta$ ig-h3 ( $A, B, C)$ and ColX (D, E, F) mRNA in the mouse femur at postnatal day 7 (P7), P14, and P21. Radioactive anti-

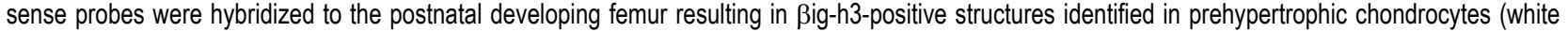
arrow) whereas ColX-positive structures identified in hypertrophic chondrocytes (red arrowhead). The tissue morphology was examined under the bright field (row 1) and in situ hybridization signal was observed under the dark field of the fluorescence microscope (row 2). 
E12.5, and continuously observed during the cartilaginous formation (Ferguson et al., 2003). In particular, $\beta$ ig-h3 transcripts appeared abundant in proliferating chondrocytes, whereas they appeared much less frequently in hypertrophic chondroctyes. Corresponding to the previous reports of $\beta$ ig-h3 transcripts, this study showed the expression pattern of $\beta$ ig-h3 protein during mouse development. In vivo histological analysis of this study explained that the expression of $\beta$ ig-h3 protein was abundant in prehypertrophic chondrocytes, perichondrium, and periosteum from embryonic to postnatal growth, but not in hypertrophic chondrocytes. In comparison to TGF- $\beta 1$ expression restricted to the proliferative and upper hypertrophic zones in chondrocytes (Horner et al., 1998), this result suggests that $\beta$ ig-h 3 may have some critical roles related to the function of TGF- $\beta$ during chondrocyte differentiation and endochondral ossification. Furthermore, this present study with the expression pattern of proteins is more appropriate than transcripts to elucidate the role of $\beta$ ig-h3 as a functional protein in endochondral ossification.

Mouse embryonic carcinoma derived chondrogenic cell line, ATDC5 cells are frequently used for in vitro models of chondrogenesis (Akiyama et al., 1997). In the presence of insulin, ATDC5 cells proliferate and differentiate to form cartilage nodules, and then express type II collagens, aggrecans, and parathyroid hormone (PTH)/PTH-related peptide (PTHrP) receptors. With further differentiation, ATDC 5 cells are hypertrophied and finally express type X collagens (Shukunami et al., 1996, 1997). Finally, mineralized ECM is generated at the last stages of ATDC5 cell differentiation. TGF- $\beta$ is important to control chondrocyte and osteoblast differentiation, and in particular, it regulates in vitro chondrogenic differentiation in ATDC5 cells with the increased expression of fibronectin isoforms (Han et al., 2005). Here the pattern of $\beta$ ig-h3 expression during chondrocyte differentiation in ATDC5 cells was explained. The in vitro differentiation study of ATDC5 cells showed that Big-h3 expression was highly increased at the early stages of differentiation, followed by an abrupt decrease at the late stages. Moreover, the expression pattern of $\beta$ ig-h3 was concurrent with the pattern of TGF- $\beta 1,-\beta 2$, and $-\beta 3$ during ATDC 5 cells differentiation. We also observed the chondrocyte maturation in the condition of $\beta$ ig-h3 overexpression which is on $\beta$ ig-h3-coated culture plates or on TGF- $\beta$-induced $\beta$ ig-h3, resulting in the only a little increase of chondrocyte maturation (data not shown). Although this in vitro data has begun to clarify the role of $\beta$ ig-h3 in chondrocyte maturation, further in vivo studies with $\beta$ ig-h3-overexpressed animals will continue to elucidate the function of Big-h3 in chondrocyte maturation.

Taken together, this study suggests that $\beta$ ig-h 3 is mainly induced by TGF- $\beta 1$ at the prehypertrophic chondrocytes and may mediate the function of TGF- $\beta$ during endochondral ossification. This implies more exactly the role of $\beta$ ig-h3 mediated by the function of TGF- $\beta$ in prehypertrophic - hypertrophic differentiation during endochondral ossification.

\section{Acknowledgments}

This work was supported by BioMedical Research Institute grant, Kyungpook National University Hospital (2005) (to J-E.K.), the grant No. RTI04-01-01 from the Regional Technology Innovation Program of the Ministry of Knowledge Economy (MKE) (to I-S.K.), and the Brain Korea 21 Project in 2008

\section{References}

Akiyama H, Shigeno C, Hiraki Y, Shukunami C, Kohno H, Akagi M, Konishi J, Nakamura T. Cloning of a mouse smoothened cDNA and expression patterns of hedgehog signalling molecules during chondrogenesis and cartilage differentiation in clonal mouse EC cells, ATDC5. Biochem Biophys Res Commun 1997;235:142-7

Chen Q, Johnson DM, Haudenschild DR, Goetinck PF. Progression and recapitulation of the chondrocyte differentiation program: cartilage matrix protein is a marker for cartilage maturation. Dev Biol 1995;172:293-306

Ferguson JW, Mikesh MF, Wheeler EF, LeBaron RG. Developmental expression patterns of Beta-ig (betalG-H3) and its function as a cell adhesion protein. Mech Dev 2003;120:851-64

Gibson G., Lin DL, Wang X, Zhang L. The release and activation of transforming growth factor beta2 associated with apoptosis of chick hypertrophic chondrocytes. J Bone Miner Res 2001;16:2330-8

Goetinck PF. Proteoglycans in development. Curr Top Dev Biol 1991;25:111-31

Hall BK, Miyake T. Divide, accumulate, differentiate: cell condensation in skeletal development revisited. Int J Dev Biol 1995;39:881-93

Han F, Adams CS, Tao Z, Williams CJ, Zaka R, Tuan RS, Norton PA, Hickok NJ. Transforming growth factor-beta1 (TGF-beta1) regulates ATDC5 chondrogenic differentiation and fibronectin isoform expression. J Cell Biochem 2005; 95:750-62

Hashimoto K, Noshiro M, Ohno S, Kawamoto T, Satakeda H, Akagawa Y, Nakashima K, Okimura A, Ishida H, Okamoto T, Pan H, Shen M, Yan W, Kato Y. Characterization of a cartilage-derived 66-kDa protein (RGD-CAP/beta ig-h3) that binds to collagen. Biochim Biophys Acta 1997;1355:303-14 Horner A, Kemp P, Summers C, Bord S, Bishop NJ, Kelsall 
AW, Coleman N, Compston JE. Expression and distribution of transforming growth factor- $\beta$ isoforms and their signaling receptors in growing human bone. Bone 1998;23:95-102

Inada M, Yasui T, Nomura S, Miyake S, Deguchi K, Himeno M, Sato M, Yamagiwa H, Kimura T, Yasui N, Ochi T, Endo N, Kitamura Y, Kishimoto T, Komori T. Maturational disturbance of chondrocytes in Cbfa1-deficient mice. Dev Dyn 1999; 214:279-90

Jung MY, Thapa N, Kim JE, Yang JD, Cho BC, Kim IS Recombinant tetra-cell adhesion motifs supports adhesion, migration and proliferation of keratinocytes/fibroblasts, and promotes wound healing. Exp Mol Med 2007;39:663-72

Kim JE, Kim SJ, Lee BH, Park RW, Kim KS, Kim IS. Identification of motifs for cell adhesion within the repeated domains of transforming growth factor-beta-induced gene, ßig-h3. J Biol Chem 2000a;275:30907-15

Kim JE, Kim EH, Han EH, Park RW, Park IH, Jun SH, Kim JC, Young MF, Kim IS. A TGF-beta-inducible cell adhesion molecule, betaig-h3, is downregulated in melorheostosis and involved in osteogenesis. J Cell Biochem 2000b;77: 169-78

Kim JE, Jeong HW, Nam JO, Lee BH, Choi JY, Park RW, Park JY, Kim IS. Identification of motifs in the fasciclin domains of the transforming growth factor-beta-induced matrix protein betaig-h3 that interact with the alphavbeta5 integrin. J Biol Chem 2002;277:46159-65

Kim JE, Kim SJ, Jeong HW, Lee BH, Choi JY, Park RW, Park JY, Kim IS. RGD peptides released from betaig-h3, a TGF-beta-induced cell-adhesive molecule, mediate apoptosis. Oncogene 2003;22:2045-53

LeBaron RG, Bezverkov KI, Zimber MP, Pavelec R, Skonier J, Purchio AF. Beta IG-H3, a novel secretory protein inducible by transforming growth factor-beta, is present in normal skin and promotes the adhesion and spreading of dermal fibroblasts in vitro, J Invest Dermatol 1995;104:844-9

Lee BH, Bae JS, Park RW, Kim JE, Park JY, Kim IS. betaig-h3 triggers signaling pathways mediating adhesion and migration of vascular smooth muscle cells through alphavbeta5 integrin. Exp Mol Med 2006;38:153-61

Metsaranta M, Garofalo S, Decker G, Rintala M, de Crombrugghe $\mathrm{B}$, Vuorio $\mathrm{E}$. Chondrodysplasia in transgenic mice harboring a 15-amino acid deletion in the triple helical domain of pro alpha 1 (II) collagen chain. J Cell Biol 1992;118:203-12

Nakata K, Ono K, Miyazaki J, Olsen BR, Muragaki Y, Adachi E, Yamamura K, Kimura T. Osteoarthritis associated with mild chondrodysplasia in transgenic mice expressing alpha 1 (IX) collagen chains with a central deletion. Proc Natl Acad Sci USA 1993;90:2870-4

Ohno S, Doi T, Tsutsumi S, Okada Y, Yoneno K, Kato Y, Tanne K. RGD-CAP ( $\beta$ ig-h3) is expressed in precartilage condensation and in prehypertrophic chondrocytes during cartilage development. Biochim Biophys Acta 2002;1572:114-22
Olsen BR, Reginato AM, Wang W. Bone development. Annu Rev Cell Dev Biol 2000;16:191-220

Park MH, Shin HI, Choi JY, Nam SH, Kim YJ, Kim HJ, Ryoo HM. Differential expression patterns of Runx2 isoforms in cranial suture morphogenesis. J Bone Miner Res 2001;1 6:885-92

Park SW, Bae JS, Kim KS, Park SH, Lee BH, Choi JY, Park JY, Ha SW, Kim YL, Kwon TH, Kim IS, Park RW. Beta ig-h3 promotes renal proximal tubular epithelial cell adhesion, migration and proliferation through the interaction with alpha3beta1 integrin. Exp Mol Med. 2004;36:211-9

Schorderet DF, Menasche M, Morand S, Bonnel S, Buchillier V, Marchant D, Auderset K, Bonny C, Abitbol M, Munier FL. Genomic characterization and embryonic expression of the mouse Bigh3 (Tgfbi) gene. Biochem Biophys Res Commun 2000;274:267-74

Shukunami C, Shigeno C, Atsumi T, Ishizeki K, Suzuki F Hiraki Y. Chondrogenic differentiation of clonal mouse embryonic cell line ATDC5 in vitro: differentiation-dependent gene expression of parathyroid hormone (PTH)/PTH-related peptide receptor. J Cell Biol 1996;133:457-68

Shukunami C, Ishizeki K, Atsumi T, Ohta Y, Suzuki F, Hiraki Y. Cellular hypertrophy and calcification of embryonal carcinoma-derived chondrogenic cell line ATDC5 in vitro. J Bone Miner Res 1997:12:1174-88

Skonier J, Neubauer M, Madisen L, Bennett K, Plowman GD, Purchio AF. CDNA cloning and sequence analysis of betaig-h3, a novel gene induced in a human adenocarcinoma cell line after treatment with transforming growth factor-beta. DNA Cell Biol 1992;11:511-22

Skonier J, Bennett K, Rothwell V, Kosowski S, Plowman G Wallace P, Edelhoff S, Disteche C, Neubauer M, Marquardt $\mathrm{H}$, Rodgers J, Purchio AF. beta ig-h3: a transforming growth factor-beta-responsive gene encoding a secreted protein that inhibits cell attachment in vitro and suppresses the growth of $\mathrm{CHO}$ cells in nude mice. DNA Cell Biol 1994; 13:571-84

Tacchetti C, Tavella S, Dozin B, Quarto R, Robino G, Cancedda R. Cell condensation in chondrogenic differentiation. Exp Cell Res 1992;200:26-33

Thapa N, Kang KB, Kim IS. Big-h3 mediates osteoblast adhesion and inhibits differentiation. Bone 2005;36:232-42

Thapa N, Lee BH, Kim IS. TGFBIp: A versatile matrix molecular induced by TGF- $\beta$. Int J Biochem Cell Biol 2007; 39:2183-94

Thorp BH, Anderson I, Jakowlew SB. Transforming growth factor-beta 1, -beta 2 and -beta 3 in cartilage and bone cells during endochondral ossification in the chick. Development 1992; 114:907-11

Yang X, Chen L, Xu X, Li C, Huang C, Deng CX. TGF-beta/Smad3 signals repress chondrocyte hypertrophic differentiation and are required for maintaining articular cartilage. J Cell Biol 2001;153:35-46 